\title{
ANTARCTIC TREATY
}

Antarctica is an island continent some $15.5 \mathrm{~m}$. sq. $\mathrm{km}$ in area which lies almost entirely within the Antarctic Circle. Its surface is composed of an ice sheet over rock, and it is uninhabited except for research and other workers in the course of duty. It is in general ownerless: for countries with territorial claims, see ARGENTINA; AUSTRALIA: Australian Antarctic Territory; CHILE; FRANCE: Southern and Antarctic Territories; NEW ZEALAND: Ross Dependency; NORWAY: Queen Maud Land; UNITED KINGDOM: British Antarctic Territory.

12 countries which had maintained research stations in Antarctica during International Geophysical Year, 1957-58 (Argentina, Australia, Belgium, Chile, France, Japan, New Zealand, Norway, South Africa, the USSR, the UK and the USA) signed the Antarctic Treaty (Washington Treaty) on 1 Dec. 1959. Austria, Brazil, Bulgaria, Canada, China, Colombia, Cuba, Czech Republic, Denmark, Ecuador, Estonia, Finland, Germany, Greece, Guatemala, Hungary, India, Italy, South Korea, North Korea, the Netherlands, Papua New Guinea, Peru, Poland, Romania, Slovakia, Spain, Sweden, Switzerland, Turkey, Ukraine, Uruguay and Venezuela subsequently acceded to the Treaty. The Treaty reserves the Antarctic area south of $60^{\circ} \mathrm{S}$. lat. for peaceful purposes, provides for international cooperation in scientific investigation and research, and preserves, for the duration of the Treaty, the status quo with regard to territorial sovereignty, rights and claims. The Treaty entered into force on 23 June 1961. The 45 nations party to the Treaty (27 full voting signatories and 18 adherents) meet biennially.

An agreement reached in Madrid in April 1991 and signed by all 39 parties in Oct. imposes a ban on mineral exploitation in Antarctica for 50 years, at the end of which any one of the 27 voting parties may request a review conference. After this the ban may be lifted by agreement of three quarters of the nations then voting, which must include the present 27.

Website: http://www.nsf.gov/od/opp/antarct/anttrty.htm

\section{Further Reading}

Elliott, L. M., International Environmental Politics: Protecting the Antarctic. London, 1994 Jørgensen-Dahl, A. and Østreng, W., The Antarctic Treaty System in World Politics. London, 1991

Meadows, J. et al., The Antarctic [Bibliography]. Oxford and New Brunswick (NJ), 1994

\section{INTER-PARLIAMENTARY UNION (IPU)}

Founded in 1889 by William Randal Cremer (UK) and Frédéric Passy (France), the Inter-Parliamentary Union was the first permanent forum for political multilateral negotiations. The Union is a centre for dialogue and parliamentary diplomacy among legislators representing every political system and all the main political leanings in the world. It was instrumental in setting up what is now the Permanent Court of Arbitration in The Hague.

Activities. The IPU fosters contacts, co-ordination and the exchange of experience among parliaments and parliamentarians of all countries; considers questions of international interest and concern, and expresses its views on such issues in order to bring about action by parliaments and parliamentarians; contributes to the defence and promotion of human rights(an essential factor of parliamentary democracy and development; contributes to better knowledge of the working and development of representative institutions and to the strengthening of representative democracy.

Membership. The IPU had 144 members and five associate members in Nov. 2002.

Headquarters: Chemin du Pommier 5, C.P. 330, 1218 Le Grand Saconnex, Geneva 19, Switzerland.

Website: http://www.ipu.org

Secretary-General: Anders B. Johnsson (Sweden). 